made payable to the treasurer. Pamphlets containing the rules of the Congress and other information can be obtained in England from Mr. S. E. Carr, The Chemical Society, Burlington House, Piccadilly, London, W.1.

Groups and sections of the ninth International Congress of Pure and Applied Chernistry have been organised as follows: (1) Physical and Theoretical Chemistry, pure (electrochemistry, photochemistry), applied (colloid chemistry, rubber, tanning and leather materials, electrometallurgy); (2) Inorganic Chemistry, pure, applied (glass, ceramics, cement, mineralogy, metallurgy); (3) Organic Chemistry, pure, applied (colouring materials, explosives, sugars, starches, cellulose, paper, fats, oils, soaps, colours, paints, varnishes); (4) Biological Chemistry, pure, applied (medical and pharmaceutical chemistry, fermentation industries); (5) Analytical Chemistry, pure, applied; (6) Agricultural Chemistry; (7) History and Teaching of Chemistry, Economies and Chemical Legislation. Papers may be in the language with which the author is familiar, but the organising committee suggests the use of such languages as will avoid typographical difficulties when rendered into Latin type. Summaries must be given in English, French, German, Italian or Spanish. Scientific communications intended for the Congress should be forwarded by February 5, 1934. The Congress will comprise general lectures ; lectures, followed by discussions, in the various groups; and original communications. The general lectures will deal with mineral chemistry, organic chemistry and biochemistry.

\section{Metric System in China and Turkey}

ON December 1 of last year, the Chinese Government issued a notice to the effect that the metric system of weights and measures would be introduced into the Customs service on February 1. According to the Shanghai correspondent of the Times, the metric system has been applied in the collection of the salt tax since January 1 . On the same date, Turkey adopted metric weights and measures, and that system is now obligatory throughout Turkish dominions in Europe and Asia. Thus Turkey, until recently one of the most backward of the European powers, has come into line with the majority of modern States, and no doubt her commerce and industry will benefit from the consequent simplification. Several attempts have, of course, been made to introduce decimal weights, measures and coinage into Great Britain, but the most that has been achieved is the legalisation of the use of metric weights and measures, and the adoption of such terms as 'metric ton'. It would seem that the fuller use of the metric system in Great Britain, like the introduction of the 24-hour clock, is unduly delayed by the prevalent inertia of unscientific public opinion.

\section{Non-Reflecting Windows}

NON-REFTECTING windows are beginning to be used for shops. The reflectionless window is a British invention. It is made of a concave sheet of glass so constructed that the light from all sources incident on it is reflected to two black boards arranged one at the top and one at the bottom of the glass. The eye of the observer looking at the gless from in front is completely unaffected by any of the reflected light, the result being that it is very difficult to believe that there is any glass between the objects displayed and the observer. The prospective buyer therefore views the goods more clearly and is not distracted by images. It is also claimed that the reflectionless window effects an appreciable saving in the cost of artificiable lighting, since every lamp in use is able to give its full illuminating value and has not to compete with the disturbing effects of outside rays reflected by the window. The new window is applicable to all shops whether new or old, and for maintenance it costs no more than an ordinary plate-glass window. An illustrated description of the reflectionless window is given in the Illuminating Engineer of January, 1934.

\section{Expedition to East Africa}

AN important expedition for archæological and geological exploration of the Northern Frontier Provinee of Kenya Colony left England on January 4. Its purpose is to carry out a topographical and geological survey in the neighbourhood of Lake Rudolph in the great Rift Valley of East Africa. Particular attention will be given to the search for evidence of an archæological or palæontological nature bearing upon the problem of the antiquity of man in the area, in the hope of extending further northward knowledge supplementing the discoveries made by Dr. L. S. B. Leakey in Kenya and Tanganyika. The personnel of the expedition will include two surveyors, Mr. R. C. Wakefield of the Sudan Survey and Mr. W. H. R. Martin of the University of Oxford. Mr. D. G. MacInnes will be responsible for mammalian palæontology, and Mr. J. F. Millard will act as archæologist. Dr. W. Dyson, medical officer of the expedition, will collect zoological specimens and Mr. V. E. Fuchs, who is the leader, is in charge of geology. The work of the expedition, which is supported by a number of learned societies, including the Royal Society, the Royal Geographical Society and the British Association, is planned to occupy about a year.

\section{Overhead Line Distribution Outside Great Britain}

AT the meeting of the Overhead-Lines Association in London on September 20, the methods used in North America and Scandinavia for distributing overhead lines were discussed. Mr. A. L. Stanton, president of the Association, said that it is difficult to make comparisons between the methods used in different countries, as the everyday conditions vary widely. In the United States, not more than five per cent of the street lighting is done by gas and not more than 25 per cent of the factory supplies comes from independent stations. The early development of many American supply systems was governed mainly by utilitarian considerations, not much attention being paid to securing continuous service, voltage regulation and avoidance of danger risks. 